\title{
Consumer Satisfaction and Sustainable Loyalty in Retail: Perspective from Serice Quality and Perceived Price
}

\author{
Meylia Amanatul Rochma ${ }^{1}$ Devy Eleonora Julya Christanti Jun ${ }^{1}$ Achmad Yanu Alif \\ Fianto $^{1 *}$
}

${ }^{I}$ Management Department, Faculty of Economy and Business, Universitas Dinamika, Indonesia

"Corresponding author. Email: achmadyanu@gmail.com

\begin{abstract}
This research investigates the effect of service quality and price perception on customer satisfaction and the effect of customer satisfaction on customer loyalty. This research also seeks to investigate the mediating role of customer satisfaction on the relationship between service quality and price perception with customer loyalty. This research focuses observations on 100 students in Sidoarjo who have made purchases in Indomaret- Sidoarjo. To test the research hypothesis, this research adopted the Structural Equation Model-Partial Least Square (SEM-PLS) technique using SmartPLS. This research found that customer satisfaction has a significant effect on customer loyalty and price perception also has a significant effect on customer loyalty. However, this study actually proves that service quality apparently has no significant effect on customersatisfaction.
\end{abstract}

Keywords: Consumer Satisfaction, Customer Loyalty, Service Quality, Price Perspective

\section{INTRODUCTION}

At this time the development of retail business in the country of Indonesia shows positive popularity, this is evident from the increasing number of minimarket markets each year. Strong competition in the retail industry requires that the domestic retail business be managed professionally and can serve consumers, so that the service strategy is to attract consumers by observing pricing policies, and customer satisfaction. Pricing strategies are needed and satisfaction with consumers to enable consumer loyalty in the field of retail business that is run.

In the other side, at this time the COVID-19 epidemic (coronavirus disease) is widespread. This can be attributed to consumer loyalty because consumers must see whether the retail has provided safety services so that it can lead to consumer confidence in buying it at retail. By providing safe and comfortable services consumers will be satisfied with this and remain loyal to the retail. Customer loyalty can usually be referred to as a person's loyalty to a product, a service, and a company. Customer loyalty is an expression and continuity of customer satisfaction by implementing the services offered by the company, and also customers who are loyal to the company[1]. Consumer loyalty can have a significant impact on the development of a company's business, this can occur because the costs required to attract consumers are higher than the rate to retain loyal customers[2].

The loss of consumers will cause the collapse of the company. Therefore, businesses need to retain consumers by increasing loyalty. Customer loyalty can be influenced by customer satisfaction. Satisfaction is based on feelings of disappointment or feeling felt by someone by comparing the performance of the product with the desired performance. All companies need to maintain a competitive market position and keep customers satisfied with better service.

In addition to customer satisfaction, other things can have an impact on customer loyalty, especially those that benefit quality[3]. Service quality is an important calculation for companies that focus on achieving 


\section{Procedia Business and Financial Technology}

Proceedings of the 2nd International Conference on Business and M anagement of T echnology (ICO N BM T 2020) - Part 2

customer loyalty[4]. Knowledgeable people describe service quality as a dynamic situation and relate to service products, humanity, progress, and the environment in which customers can meet and exceed buyers' needs[5]. Quality of service is the key to a company's victory, especially in the retail industry[6]. Service quality must be the main focus of the company's consideration. This explanation is based on the results of a survey conducted by experts that there is a quality of service with opportunities that have a positive impact on customer loyalty at the convenience store[7]. Price is the value for money that is expected to have a mixture of products and services that accompany it. Perception-based on experts is the progress of individualsin selecting, organizing, and translating stimuli that enter into a comprehensive illustration[8].

Pricing strategies are not the only method used to solve different problems for a company, but each company must make decisions about the price problem appropriately[9]. One of the company's methods applied to achieve customer loyalty is to offer consumers reasonable and reasonable prices. Indomart is a trading company or retail business that aims to build the best retail distribution in Indonesia that is claimed by the wider community. However, for the last three years, the data stated that Indomart was under Alfamart.

Sidoarjo is an area that is quite competitive in the retail sector such as minimarkets. Indomart can compete with other minimarkets in Sidoarjo, one of Indomart found on Jl. Jenggala No.22, Megersari, Gedangan, Kec. Gedangan, Sidoarjo Regency, East Java. Indomart Jenggala 2 has more points compared to other Indomart, such as the total number of items that are complete, a large parking area, and a large storefront area to rest. Based on this opportunity, analysts surveyed 30 respondents through three points: service quality, customer loyalty, and price perception. According to previous thoughts, almost all customers are not happy with this indicator. Analysts were very curious about investigating with the title: "Effect of Service Quality and Price Perception on Customer Loyalty with Consumer Satisfaction as Mediation Variables" because the results of dissatisfaction were significantly greater.

\section{LITERATURE REVIEW AND HYPOTHESES}

\subsection{Simultan Effect of Service Quality and Perceived Price toward CustomerSatisfaction}

Consumer satisfaction is shown by the view of consumers about the purchase. Satisfaction is satisfaction or dissatisfaction with which the performance of a product (result) is proportional to the expected performance of the user after it occurs[3]. After buying, the next stage that will be experienced by consumers is the ongoing purchase stage. At this stage, consumer behavior is further influenced by a certain level of satisfaction or dissatisfaction[9]. The results of consumers who feel happy, consumers will make purchases again[5].

Building customer satisfaction is part of the company's efforts to excel and benefit in today's market. Building customer satisfaction further strengthens the company's relationship with consumers. The goal that the company focuses on is building consumer loyalty. Satisfied customers are stated as capital for the company in the survival of the company. Building customer satisfaction has its uses in providing a good basis for repeat purchases, building customer loyalty, and making word of mouth (WOM) deemed useful is very important in the company. Quality of service is the first thing that affects customer satisfaction[2]. Quality of service is very important for the success of the company[1].

The quality of service of a product or service depends on the ability of producers to continue to meet consumer expectations[8]. Customers who are indirectly satisfied build loyalty[9], encourage word of mouth recommendations, and increase customer awareness of the product[5]. Thus, the quality of play certainly be the main thing that must be considered by the company. In the increasingly fierce competition, many manufacturers respond and meet the needs or expectations of customers, which makes the main goal of the company must focus on customer satisfaction[7]. This is illustrated by the number of companies that implement commitments to customer satisfaction[9]. The key that is useful as competitive advantage is providing more value and customer satisfaction with products that have high quality at reasonable prices and are quite competitive[8].

The second factor that influences customer satisfaction is price perception. Low prices are an important source of satisfaction for sensitive consumers, but prices may not be too important for consumers who are not price sensitive. In retail business midwives, the price component is very important and the relationship to satisfaction is also very important. Perception is the process of selecting, organizing, and defining stimuli and information, and turning them into broader perspectives.

Therefore, assessing the price of a product is not expensive, cheap, or simple for anyone, because it depends on the perception of consumers who are motivated by the environment and personal circumstances. The reality of valuing the price of a product depends not only on absolute nominal value, but also on price perception. Consumer price perception usually depends on market perception (perceived price differences) and benchmark prices (reference prices). This is the basis for establishing the proposed hypothesis, namely:

\section{H1 : Service quality and perceived price simultaneously have significant effect on customer satisfaction}




\section{Procedia Business and Financial Technology}

Proceedings of the 2nd International Conference on Business and M anagement of T echnology (ICO N BM T 2020) - Part 2

\subsection{Partial Effect of Service Quality and Perceived Price toward CustomerSatisfaction}

Building customer satisfaction is an effort to win and stay competitive in the market for the company[8]. Building customer satisfaction further strengthens the company's relationship with consumers[2]. The company's main goal is to build customer loyalty[1]. Customers who have satisfaction are the company's capital for its existence[6]. The advantage of customer satisfaction is that it provides customer satisfaction as a basis for repeat purchases from customers, builds loyalty provided by customers, and creates recommendations from customers to other customers as a valuable opportunity forbusinesses.

Quality of service is a major factor in corporate concern[9]. The existence of a fairly tight competition with evidence of the increasing number of business people in meeting the demands and needs of consumers, all business people are expected to remain focused on customer satisfaction where it is the company's main goal[8].

This can be illustrated in the company's growth, including commitment to customer satisfaction[2]. The key to excel in competition is to provide more value and satisfaction to consumers by offering a variety of quality products at reasonable prices and competitive prices.

Knowledge of consumer prices can translate how much price information is received and provided. The price of the buyer's mind is the price used as a comparison and is called the internal reference price. Internal reference prices are prices that buyers consider reasonable in the future, because they are already low or high in the minds of consumers. Specifically, every consumer knows the relationship between the price of the product purchasedand the expected level. In addition, the price quota given is proportional to past events and consumer desires, so that prices given by companies to quality products can be accepted. This is the basis for developing the proposed hypothesis, namely:

\section{H2 : Service quality and perceived price partially have significant effects toward customer satisfaction}

\subsection{Customer Satisfaction and Loyalty}

Consumer satisfaction is an important factor in many business activities [9]. Customer satisfaction is the customer's reaction to determine the perceived difference between past perceptions and the actual results of a product. This has a positive impact on the business and fulfills the wants and needs of customers[8]. If consumers are happy with the product, of course consumers will continue to use it or consume it[2].

Consumers can also feel the performance, so consumers can make different decisions depending on the results of the company's performance. Ranking can be satisfaction and unhappiness. Customers who are satisfied with the value provided by the product or service tend tobe loyal or long-term customers. Customer loyalty and satisfaction have a relationship between brand and customer and have the simple reason that customers buy back the same product and suggest other products byword of mouth. Customer loyalty is often defined as a brand or manufacturer commitment that focuses on a positive attitude, which is manifested in regular repurchases. This is the basis for establishing the proposed hypothesis, namely:

\section{H3 : Customer Satisfaction have significant effect toward customer loyalty}

\subsection{Customer Satisfaction as Mediating Variable in the Relationship betweenService Quality and Customer Loyalty}

Service qualitywill have an important role in shaping public perception that can influence customers in the level of loyalty to certain companies. Good service quality can result in high customer satisfaction so as to increase customer loyalty[1]. Customer loyalty is built primarily from quality services[8].

Therefore, service quality is at the heart of business problems driven by customers[4]. Good service is one of the keys to success in creating customer satisfaction where customers become loyal to the company, but the company survives and wins the market[9]. Loyalty can be defined as the willingness of customers to use certain products or services continuously in the long run, so that consumers have a sense of voluntary to recommend the company's products to other people. The severe challenges for marketing also need to make customers remain loyal and even add the level of the number of purchases based on satisfaction with service quality provided by the company. The higher the quality of services provided, the higher the customer loyalty level. According to many experts, service quality is such that the company's service function meets consensus expectations. The greater the gap between service expectations and capacity, and vice versa, the greater the level of consumer dissatisfaction. Next, the proposed hypothesis is:

\section{H4 : Service quality has a significant effect on customer loyalty with customer satisfaction as a mediating variable}

\subsection{Customer Satisfaction as Mediating Variable in the Relationship betweenPerceived Price and Customer Loyalty}

(1)

(1)




\section{Procedia Business and Financial Technology}

Proceedings of the 2nd International Conference on Business and M anagement of T echnology (ICO N BM T 2020) - Part 2

The information contained in price perception is understood by consumers so that it gives a deep meaning to consumers. The company's decision about price perception must be weighed against market segmentation to be right on target. Of course consumers will compare price perception of one brand to another[2]. Specifically, consumers will know the relationship between the expected level and the expected nominal price of the product purchased. For a company, efforts to be loyal to its customers can be done through stages rather than directly. If the company determines that quality does not reflect product benefits, customer satisfaction will decrease[1]. Conversely, customer loyalty increases when companies set prices based on profits generated by consumers from the company's products.

The existence of customer satisfaction that is created can bridge the consumer to become lloyal to a company[9]. The success of the company in retaining consumers will be able to easily improve financial performance, where if the financial performance is very good, the company will survive in the survival of the company[8]. There are several stages for loyal or loyal customers. Stages that will be faced not with a short time. At some stages, different requirements have different emphases and concerns from time to time. Companies that can look after and meet their needs at every stage will have a great opportunity to satisfy their customers or create consumers with the customer satisfaction it offers. Then the hypothesis is proposed, namely:

\section{H5 : Perceived price has a positive effect on customer loyalty with customer satisfaction as a mediating variable}

\section{RESEARCH METHOD}

This research is contained in quantitative research by utilizing the questions selected for the procedure as an important data source. The survey was conducted in 2020 in several universities with the Division of Business Studies. This study has three variables consisting of independent variables that cause and influence other factors. The independent variable consists of Service Quality (X1) and Price Perception (X2). Second, the dependent variable consisting of Customer Loyalty (Y) which is influenced or caused by the closeness of the independent variable. Third, the mediating variable is Consumer Satisfaction (Z). This variable mediates a causal relationship between independent variables into the dependent variable.

Service Quality Indicators consist of (1) qualityin conversation, (2) environmental quality, (3) retail procedures, (4) yield factors. Price Perception Indicators consist of (1) willingness to buy, (2) lifestyle of consumers,

(3) prices offered by other places. Indicators of customer loyalty include (1) consumers who buy products $57 / 180$ regularly,

(2) consumers who offer and recommend to other consumers, and (3) consumers who survive and are not influenced by competitors. Consumer Satisfaction Index(1) meets expectations, (2) performance perceptions, (3) customer evaluation.

The existing population and participating in this study are all customers who have made purchases at Indomart Jenggala 2 Gedangan. Techniques that have the nature of questionnaires and documentation, will be usedin this study. Data analysis techniques related to this study were conducted with the aim of testing the impact of service quality and price perceptions on customer loyalty on customer satisfaction as a mediating variable. As an instrumental question, it considers using a survey consisting of a multi-item Likert scale, and divided into five categories: "Strongly Disagree" (1) to "Strongly Agree" (5). The results of the respondents have collected 100 valid surveys from 100 surveys submitted by respondents. SmartPLS version 3 is the data analysis technique used in this study.

\section{RESULTS}

This measurement model evaluates the relationship between constructs and indicators. This measurement model consists of two stages including evaluating discriminant validity and convergent validity. Convergent validity is done by assessing construct reliability, Average Variance Extracted (AVE), and indicators of validity. The loading factor value on the validity indicator will be seen more than 0.5 with a statistical value of more than 2.0, which means that the data is valid. In this study, all indicators in the study can be declared valid because they meet the requirements of the evaluation of validity indicators.

All of the values of loading factors of the indicators that have been used in the measurement of variables in this study that are worth more or above 0.5 as well as the results of the test of the significance of loading factors with t statistics. So at that point, it can be assumed that the indicators in this study have a fairly large level of validity because the loading factor correlates with this indicator and its construct.

All loading factors having at a value of more than

2.0 are shown in table 1 so that all the indicators of this research can be stated that the validity is significant. Reliability by assessing the reliability of the conron or Cronbachs alpha output can establish furthermeasurements of convergent validity. Ideal reliability has a combined reliabilityvalue above 0.70 and AVE values indicate above

0.50. In the other side, the results of the AVE test and composite reliability, which proves that all constructs in 


\section{Procedia Business and Financial Technology}

Proceedings of the 2nd International Conference on Business and M anagement of T echnology (ICO N BM T 2020) - Part 2

this study can be said and can be relied upon because these results have a composite value above 0.70 and an AVE value above 0.50 .

There are two stages, the first is to measure specifically the cross-loading assessment and the second is the stage of comparing the square of correlations that will be developed in AVE assessment. Cross-loading has several criteria which are emphasized by all indicators that measuring constructs must have a greater relationship with the construct itself compared to among other constructs. Each indicator in this study has a higher correlation to each construct than the other constructs. Therefore, it can be concluded that the factors in this study generally have a large discriminant validity value. Then proceed to the correlation comparison test with the AVE construct. The value for the maximum correlation in Customer Satisfaction is 0.609 , and the AVE rating is 0.879 which is higher than the maximum correlation value.

The assessment of the maximum correlation of the other variables in this study seems to be smaller than the rating of each AVE. Thus it can be concluded that the research carried out holds good validity of thediscriminant. The next stage in this research, after testing the measurement model has been fulfilled, then the structural model testing can be done. This test includes evaluating the significance of the path relationship and the value of $R^{2}$. Significant path relationships is seen in the effect of customer satisfaction on customer loyalty and purchasing decisions, the effect of perceived price on brand image and price perception on customer satisfaction. But the quality of service does not affect satisfaction.

\section{DISCUSSION}

In this study, the influence of service quality does not have a significant positive effect on customer satisfaction. This is based on the fact that customers do not really care about the quality of service from Indomaret employees, becausewhat is done by Indomaret employees is a standard that must be done so as not to make something stand out so as to make customers satisfied with Indomaret.

This study also found that price perception has a positive and significant impact on customer satisfaction. As with Indomaret services, prices advertised by Indomaret tend to provide fulfillment to customers, because customers feel that the prices advertised by Indomaret are following customer wishes.

In this study, thinking about customer satisfaction can be proven to have a positive and significant impact on consumer loyalty. Customer satisfaction can be said to have a positive and significant impact on customer loyalty if customer satisfaction towards Indomaret is higher and the loyalty given to Indomaret by customers will be high as well. Therefore Indomaret must increase customer satisfaction by increasing promotions and thinking of $58 / 180$ strategies in pricing so that customers are more satisfied and make customers more loyal to Indomaret.

\section{CONCLUSION}

This research illustrates that service quality does not significantly affect customer satisfaction because the customer feels that the services provided by Indomaret employees should be done. Besides, there is a perception of the price that has a significant impact or influence on customer satisfaction. The perception that will be borne by customers towards prices can trigger customers to be satisfied with Indomaret because in Indomaret there are manypromising promos and discounts so that customers are satisfied when shopping at Indomaret. Customer satisfaction also affects customer loyalty. Customer loyalty has important value for a company, customer loyalty will be able to grow if the customer is satisfied with what has been offered by Indomaret.

\section{REFERENCES}

[1] A. Y. A. Fianto, "The Antecedents of Purchase Decision for Hijab Fashion Products," Manajemen, vol. 12, no. 1, pp. 154-165, 2020.

[2] R. Santoso, R. A. Shintawati, and A. Y. A. Fianto, "Pengaruh Marketing Mix Produk Jasa terhadap Keputusan Berkunjung Wisata Bahari Jawa Timur," Kinerja, vol. 17, no. 1, pp. 69-79, 2020.

[3] D. Y. Riyanto, N. Andriyanto, A. K. Riqqoh, and A.Y. A. Fianto, "A Conceptual Framework for Destination Branding in Jawa Timur, Indonesia," Maj. Ekon., vol. XXIV, no. 1411, pp. 149-157, 2019.

[4] R. Santoso, R. Shinta, and A. Y. A. Fianto, "Composing Marketing Mix for Better Destination Brand in Jawa Timur, Indonesia," Maj. Ekon., vol. XXIV, no. 1411, pp. 158-167, 2019.

[5] A. Jafar, A. Y. A. Fianto, and S. P. Yosep, "Penciptaan Buku Ilustrasi Permainan Tradisional Sebagai Upaya Pelestarian Warisan Budaya Lokal," Art Nouv., vol. 3, no. 1, 2014.

[6] R. D. Pinasti, A. Y. A. Fianto, and W. Hidayat, "Penciptaan Buku Komik Sebagai Upaya Pengenalan Permainan Tradisional Kepada Remaja," Art Nouv., vol. 4, no. 1, 2015.

[7] E. Y. Ikawira and A. Y. A. Fianto, "Penciptaan Buku Ilustrasi Legenda Reog Sebagai Upaya Mengenalkan Budaya Lokal kepada Anak-Anak," Art Nouv., vol. 3, no. 1, 2014.

[8] R. Santoso, R. Shinta, and A. Y. A. Fianto, 


\section{Procedia Business and Financial Technology \\ Proceedings of the 2 nd International Conference on Business and M anagement of T echnology (ICON BM T 2020) - Part 2}

"Pengaruh Bauran Pemasaran Jasa terhadap Keputusan Berkunjung ke Wisata Bahari Jawa Timur," Manaj. dan Bisnis, vol. 4, pp. 1-14, 2019.
[9] A. Y. A. Fianto, "Satifaction As Intervening For The Antecedents OfIntention To Revisit: Marine Tourism Context In East Java," Relasi, vol. 16, no. 1, pp. 179-207, 2020. 